\title{
Household Solid Waste Management Methods in Lafia, Nasarawa State Nigeria
}

\author{
${ }^{1}$ A. T Ogah, ${ }^{2}$ M .M. Alhassan, ${ }^{3}$ N. I. Medugu, ${ }^{4}$ A. B. Mohammed \\ ${ }^{1 \& 3}$ Department of Geography, Nasarawa State University, Keffi, P. O. Box 1022 Keffi, Nasarawa State, Nigeria \\ ${ }^{2}$ Department of Geography and Environmental Management, University of Abuja, Nigeria \\ ${ }^{4}$ Department of Urban and Regional Planning Modibbo Adama University of Technology Yola, Adamawa state
}

\begin{abstract}
The study discusses the socio-economic characteristics of household heads, types of waste generated and methods of disposal by household heads in Lafia. The study area was divided into three high, medium and low densities in terms of development. This was largely based on the data gathered through administration of questionnaire using systematic sampling methods. 270 copies of questionnaire were administered to household heads in the three areas selected, where high density area has 98; medium density area has 90 while low density area has 82 respectively. It was deduced that all the major types of municipal solid waste are generated in all the areas, and majority of household heads in the three areas use either plastic or metal buckets to collect and disposed their waste and also that the socio-economic characteristics varied in all the three areas at 5\% probability level as $0.842<2.78<4.60$. Furthermore, at $5 \%$ level of significance where $9.21>5.99$, this shows that solid waste is more of a problem in the high density area than in the medium and low density areas.
\end{abstract}

Keywords: Solid waste management, waste generated, method of disposal, Nigeria

\section{Introduction}

The final step in the waste management continuum is disposal. Here, solid waste that could not be further processed is deposited in a final "resting place". Disposal is the final action taken on any waste whereby the waste after being treated or otherwise, is released into the environment. Waste disposal takes place on land, water and in the atmosphere. It is the process, which brings waste into direct contact with the ecosystem and the last process in management, therefore in any management system, the provision of safer and adequate disposal sites, and facilities must be achieved (Gourlay, 1992; USEPA, 2000). Solid waste management practices relates to the total strategies for the collection and removal of wastes from the time it is generated to when it is adequately disposed of. This could also relate to the final treatment given to the waste in order to make it stable and environmentally friendly. Inadequacies in terms of services for the treatment of these waste leads to the pollution of biosphere, as can be seen on land, water and air. Besides they may constitute serious health hazards through bacterial and parasitic infections like cholera, dysentery, and typhoid and malaria fever. Once waste is generated what happened after constitute management. Solid waste management practices as it avail in our urban centers have been a subject of great concern. The adverse effects of such unhealthy practices upon our environment and personal health cannot be over emphasized; the escalation of this negative phenomenon if not handled properly and most seriously can lead to catastrophic health hazards.

Lafia, the study area, experienced increasing volumes of solid waste generation. With the establishment in 1996 Nasarawa Urban Development Board, one would have thought the orthodox waste management practices should have changed or improved upon, but the town is still bedeviled by the scourge of a filthy environment. Poor solid waste management practice is a threat to good health as water, land and air could be contaminated or polluted. As at 1970, the average density of solid waste from heaps/depots in Nigeria was put at $295 \mathrm{~kg} / \mathrm{m}^{2}$ with attendant implications for health, drainage and aesthetic problems (Maclaren, 1970). In a related exercise, Abumere (1983) characterized some Nigerian cities by their quantity of generated solid waste with Lagos having the largest total waste generation per annum, followed by Ibadan with $55,991 \mathrm{~kg} / \mathrm{year}$ and $55,224 \mathrm{~kg} /$ year respectively.

\section{Study Area}

\section{Material And Methods}

The study area for this study is Lafia the capital of Nasarawa State capital created in 1996. Lafia is one of the oldest town and largest settlement with the population of 78,247, 90,317 and 317,985 in 1991, 1996 and 2006 respectively (NPC 2006). The dominant tribes in the area includes, Kanuri, Alago, Hausa, Gwandara, Eggon and other indigenous tribes from various Local Government Areas (L.G.As) that make up the State, also settlers from neighboring States and other parts of the country were also in evidence. The major occupations of the people are farming, trading, and civil servants. They also engage in local crafts such as blacksmithing, calabash decoration, cap making and clothes design. 


\section{Methodology}

The objectives of this study were achieved through primary and secondary sources of data collection. The primary source of data was obtained through a structured questionnaire which was divided into two sections and administered on sampled households. The first section is the socio-economic profile of households; the second section is information on household waste generation and methods of disposal. The sample areas include Angwan Doka (High density area), Tudun Gwandara (Medium density area), and Angwan Tiv (Low density area). These three areas were selected using density of development for detailed study. A total of 270 copies of questionnaire was administered to sampled households in the three areas, were Angwan Doka was allocated 98 copies of questionnaire, Tudun Gwandara 90 copies, and Angwan Tiv has 82 copies respectively. The systematic stratified sampling techniques were used to choose the sampling units. The first house was selected at random, and then numbers were assigned to all the houses, the household number one were selected as the first Household and every fifth house in all the streets were systematically chosen until the whole areas were covered and this method was maintained for all the three areas. Statistical techniques used include; Chi-square test and Student t-test, to test if there is significant variation on the socio-economic characteristics and waste generation for the three areas.

\section{Socio-economic characteristics of household heads}

Table 1: Household Size

\begin{tabular}{|c|c|c|c|}
\hline & Angwan Doka (NHD) & Tudun Gwandara (MDA) & Angwan Tiv (LDA) \\
\hline SIZE & $\mathrm{NO} \%$ & $\mathrm{NO} \%$ & $\mathrm{NO} \%$ \\
\hline $1-10$ & 28 & 72 & 62 \\
\hline $11-20$ & 23 & 13 & 15 \\
\hline $21-30$ & 48 & 6 & 5 \\
\hline Total & 100 & 100 & 100 \\
\hline
\end{tabular}

Source: Field Work

Household size of between 1-10 persons dominates in the medium and low density areas. This may be due to the level of education and awareness on family control. This agrees with the national average family size of between 8-10 persons per household in most areas. In contrast 49 per cent in high density area have very large average family size of between 21-30 persons, and this may be due to the low level of educational attainment, cultural and the religion of most residents in this area where many marry more than one wife and control practices are nonexistent or very low. Given the differences in family sizes, it is expected that the amount of wastes generated in the high-density area should be much higher than in the medium and low density areas.

Table 2: Educational/Attainment of Household Heads

\begin{tabular}{|l|lr|lr|lc|}
\hline & \multicolumn{2}{|l|}{ Angwan Doka (NHD) } & \multicolumn{2}{l|}{ Tudun Gwandara (MDA) } & \multicolumn{2}{l|}{ Angwan tiv (LDA) } \\
\hline PRIMARY SCHOOL & 12 & 12 & 6 & 7 & 10 & 12 \\
\hline $\begin{array}{l}\text { SECONDARY } \\
\text { SCHOOL }\end{array}$ & 19 & 20 & 15 & 56 & 57 & 70 \\
\hline TERTIARY & 17 & 17 & 51 & 56 & 57 & 70 \\
\hline NON FORMAL & 8 & 8 & 7 & 8 & 2 & 2 \\
\hline NONE & 42 & 43 & 11 & 12 & 1 & 1 \\
\hline TOTAL & 98 & 100 & 90 & 100 & 82 & 100 \\
\hline
\end{tabular}

Source: Field Work

Table 2 below revealed that 43 per cent of respondents in the high-density area have no formal education compared to 12 per cent in the medium density and only 10 per cent in the low density area. Consequently, more educated people can be found in the medium and low density areas. These are either civilservants or private sector employees who possessed tertiary educationals qualifications. There is the tendency for high level of environmental awareness and consciousness in the medium and low-density area than in the high density area and this has implications on waste management.

Table 3: Occupation of Household Heads

\begin{tabular}{|c|c|c|c|c|c|c|}
\hline & \multicolumn{2}{|c|}{ Angwan Doka (MDA) } & \multicolumn{2}{|c|}{ Tudun Gwandara (MDA) } & \multicolumn{2}{|c|}{ Angwan Tiv (LDA) } \\
\hline OCCUPATION & No & $\%$ & No & $\%$ & No & $\%$ \\
\hline FARMING & 45 & 46 & 17 & 19 & 4 & 5 \\
\hline CIVIL-SERVANT & 11 & 11 & 32 & 35 & 41 & 50 \\
\hline TRADING & 16 & 16 & 18 & 20 & 12 & 15 \\
\hline $\begin{array}{ll}\text { PRIVATE } & \text { SECTOR } \\
\text { EMPLOYEES } & \\
\end{array}$ & 26 & 27 & 23 & 26 & 25 & 30 \\
\hline TOTAL & 98 & 100 & 90 & 100 & 82 & 100 \\
\hline
\end{tabular}


Source: field work

In the high density area most heads of household are farmers, while civil servants dominate in the medium and low density areas. This table clearly shows that most household heads in the medium and low density areas depends on government to earn their living. Five percent who constitutes farmers in the lowdensity areas are mostly security guards who also engage in urban agriculture and also generate waste.

Table 4: Approximate income of Household Heads per Month

\begin{tabular}{|c|c|c|c|c|c|c|}
\hline Income per month & No & $\%$ & No & $\%$ & No & $\%$ \\
\hline N5000-N2500 & 50 & 51 & 11 & 12 & 4 & 5 \\
\hline N15001-N2500 & 25 & 26 & 10 & 11 & 10 & 12 \\
\hline N25001-N3500 & 10 & 10 & 14 & 15 & 16 & 19 \\
\hline N35001-N45000 & 7 & 7 & 41 & 46 & 40 & 49 \\
\hline N450001-N55000 & 4 & 4 & 7 & 8 & 9 & 11 \\
\hline N55001-ABOVE & 2 & 2 & 7 & 8 & 3 & 4 \\
\hline TOTAL & 98 & 100 & 90 & 100 & 82 & 100 \\
\hline
\end{tabular}

Source: Field work

Table 4 shows that, income of most residents fall between $\$ 35,001-\$ 45,000$ income range and are concentrated in the medium and low density areas. Those on incomes of between $\$ 5000-15000$ per month dominate the high density area. This is not surprising as table 4.3 indicates that civil servants who are salary earners are dominant in the medium and low density areas, where as in the high density area, are mostly farmers and this have implication on waste management.

Households waste generation

Table 5: Major types of waste generated by households

\begin{tabular}{|l|lc|lc|ll|}
\hline & \multicolumn{2}{|l|}{ Angwan Doka (HDA) } & \multicolumn{2}{l|}{ Tudun gwandara (MDA) } & \multicolumn{2}{l|}{ Angwan tiv (LDA) } \\
\hline TYPES OF WASTE & No & $\%$ & No & $\%$ & No & $\%$ \\
\hline Domestic ash & 19 & 19 & 26 & 29 & 10 & 22 \\
\hline Papers & 20 & 20 & 42 & 47 & 40 & 49 \\
\hline Polythene & 9 & 9 & 19 & 21 & 10 & 12 \\
\hline $\begin{array}{l}\text { Crop residue and food } \\
\text { remains }\end{array}$ & 50 & 51 & 3 & 3 & 82 & 100 \\
\hline TOTAL & 98 & 100 & 90 & 100 & & \\
\hline
\end{tabular}

Source: Field work

Table 5 shows the major types of solid waste generated in the study areas. In the high density area, crop residues and food remains dominated by 51 per cent and the reason may be because most of the residents are farmers. Papers dominate in the medium density area, while polythene materials dominate in the low-density area. The reason in the medium and low density areas may be due to the nature of activities in these areas that leads to generation of these types of waste, or consumption patterns.

Table 6: Types of containers used for waste collection in the households

\begin{tabular}{|l|ll|ll|ll|}
\hline & \multicolumn{2}{|l|}{ Angwan Doka (HDA) } & \multicolumn{2}{l|}{ Tudun Gwandara (MDA) } & \multicolumn{2}{l|}{ Angwan Tiv (LDA) } \\
\hline Types of containers & No & $\%$ & No & $\%$ & No & $\%$ \\
\hline Plastic containers & 39 & 40 & 33 & 37 & 45 & 55 \\
\hline Metal buckets & 24 & 25 & 33 & 37 & 7 & 20 \\
\hline Cartons & 8 & 8 & 3 & 3 & 12 & 15 \\
\hline Drums & 12 & 12 & 21 & 23 & 2 & 2 \\
\hline None & 15 & 15 & - & - & 82 & 100 \\
\hline TOTAL & 98 & 100 & 90 & 100 & &
\end{tabular}

Source: Field work

Table 7 shows that plastics containers and metal buckets are the commonest means used for waste collection in the three areas. Only about 15 percentage and 2 per cent of households had no container at all. The reason may be due to awareness of health implication of care free dumping of refuse around compounds in the medium and low density areas, except for 15 per cent in the high density area that had no container at all and this is due to low level of educational attainment and environmental awareness. 
Table 7: Providers of waste collection containers in the household

\begin{tabular}{|c|c|c|c|c|c|c|}
\hline & \multicolumn{2}{|c|}{ Angwan Doka (NHD } & \multicolumn{2}{|c|}{ Tudun Gwandara (MDA) } & \multicolumn{2}{|c|}{ Angwan Tiv (LDA) } \\
\hline & & $\%$ & No & $\%$ & No & $\%$ \\
\hline Household heads & 68 & 69 & 69 & 77 & 56 & 68 \\
\hline Caretakers/land lords & 11 & 12 & 3 & 3 & 8 & 10 \\
\hline Public health agency & 9 & 9 & 7 & 8 & 5 & 6 \\
\hline $\begin{array}{l}\text { Nasarawa Urban } \\
\text { Development Board (NUDB) }\end{array}$ & 7 & 7 & 11 & 12 & 13 & 16 \\
\hline Lafia LGC & 3 & 3 & - & & - & \\
\hline TOTAL & 98 & 100 & 90 & 100 & 82 & 100 \\
\hline
\end{tabular}

Source: Field Work

71 per cent of household heads provides waste collection containers in their compounds. This clearly indicates household's interest in managing solid waste at the source. 11 per cent heads of household waste containers were provided by the Nasarawa state urban development board. These may be the 1.5 cubic metre containers placed in scattered locations within the study area. The impact of Lafia L.G.C. is not felt at all in the area.

TABLE 8: Frequency of waste clearing in the households

\begin{tabular}{|l|lc|lc|lc|}
\hline & \multicolumn{2}{|l|}{ Angwan Doka (NHD) } & \multicolumn{2}{l|}{ Tudun Gwandara (MDA) } & \multicolumn{2}{l|}{ Angwan Tiv (LDA) } \\
\hline & No & $\%$ & No & $\%$ & No & $\%$ \\
\hline Daily & 76 & 78 & 61 & 68 & 51 & 13 \\
\hline $2-3$ times week & 7 & 7 & 8 & 9 & 11 & 24 \\
\hline Weekly & 15 & 15 & 21 & 23 & 20 & 82 \\
\hline TOTAL & 98 & 100 & 90 & 100 & & 100 \\
\hline
\end{tabular}

Source: Field Work

$69 \%$ of household heads in the three areas clear their refuse daily. Significance proportion of household heads also clears their refuse weekly. With these results, it is expected that the environmental conditions in terms of solid waste management should either be good or fair, but the reverse is the case. The reason for this may have to do with the method of disposal and where a lot of waste is never carry to the final waste disposal sites and properly treated or managed.

Table 9: Method of solid waste disposal in the households

\begin{tabular}{|c|c|c|c|c|c|c|}
\hline & \multicolumn{2}{|c|}{ Angwan Doka (NHD) } & \multicolumn{2}{|c|}{ Tudun Gwandara (MDA) } & \multicolumn{2}{|c|}{ Angwan Tiv (LDA) } \\
\hline & & $\%$ & No & $\%$ & No & $\%$ \\
\hline Dumped at backyard & 19 & 19 & 19 & 21 & 5 & 6 \\
\hline $\begin{array}{l}\text { Dumped at public waste } \\
\text { depots }\end{array}$ & & 64 & 53 & 59 & 50 & 61 \\
\hline $\begin{array}{l}\text { Thrown on any open } \\
\text { space/field }\end{array}$ & 13 & 14 & 12 & 13 & 19 & 23 \\
\hline TOTAL & 98 & 14 & 90 & 100 & 82 & 10 \\
\hline
\end{tabular}

Source: Field Work

This table indicates that, those heads of household that dumped their waste at the public depots formed the majority for all the areas. This is the most acceptable means of waste disposal at the community levels, although most of the waste disposed at the depots remained at these sites for a long time before been cleared. However, the communities on their part are trying to build partnerships with the public agencies in charge of solid waste collection and disposal in Lafia.

Table 10: Persons involved in waste collection from household

\begin{tabular}{|c|c|c|c|c|c|c|}
\hline & \multicolumn{2}{|c|}{ Angwan Doka (NHD) } & \multicolumn{2}{|c|}{ Tudun Gwandara (MDA) } & \multicolumn{2}{|c|}{ Angwan Tiv (LDA) } \\
\hline Persons & No & $\%$ & No & $\%$ & No & $\%$ \\
\hline Male adult & 19 & 20 & 11 & 12 & 5 & 6 \\
\hline Female adult & 12 & 12 & 20 & 22 & 15 & 18 \\
\hline Children & 52 & 53 & 56 & 63 & 39 & 47 \\
\hline Waste vendors & 15 & 15 & 3 & 3 & 23 & 28 \\
\hline TOTAL & 98 & 14 & 90 & 100 & 82 & 100 \\
\hline
\end{tabular}

Source: Field Work 
Table 10 revealed that, collection and disposal of solid waste is done mainly by children who are assigned by their parents. Others members of the household are also involved in waste collection and disposal. All members of the family are involved to a different degree on household waste evacuation.

Table 11: Frequency of waste collection by NUDB

\begin{tabular}{|l|lc|lc|lc|}
\hline & \multicolumn{2}{|l|}{ Angwan Doka (NHD) } & \multicolumn{2}{|l|}{ Tudun Gwandara (MDA) } & \multicolumn{2}{l|}{ Angwan Tiv (LDA) } \\
\hline & No & $\%$ & No & $\%$ & No & $\%$ \\
\hline Daily & 14 & 14 & 3 & 3 & 3 & 4 \\
\hline Weekly & 18 & 18 & 31 & 35 & 42 & 51 \\
\hline Monthly & 8 & 8 & 9 & 10 & 6 & 78 \\
\hline Don't know & 58 & 59 & 47 & 52 & 31 & 100 \\
\hline TOTAL & 98 & 14 & 90 & 100 & 82 & \\
\hline
\end{tabular}

Source: Field Work

Inadequacy in solid waste disposal is wide spread throughout the study areas. This is only marginally better in the low density area where 51 per cent of household heads reported that wastes are collected weekly. The Nasarawa urban development board (NUDB) has only three functional trucks for waste collection and this is totally inadequate for Lafia town.

82 per cent of household in the high density area do not know whether the waste disposal vehicles goes to the area or not. This may be due to the lack of access roads for easy movement by vehicles in the area. Compare to 42 per cent in the medium density and 63 per cent in the low density areas who reported to have seen tippers going to the area between 1-5 times a weeks. The reason in the area may be because of access road for easy movement by waste disposal vehicles.

Table 12: Approximate number of Tipper load of waste in the study area

\begin{tabular}{|l|ll|lc|lr|}
\hline & \multicolumn{2}{|l|}{ Angwan Doka (NHD) } & \multicolumn{2}{l|}{ Tudun Gwandara (MDA) } & \multicolumn{2}{l|}{ Angwan Tiv (LDA) } \\
\hline No of tipper load waste & No & $\%$ & No & $\%$ & No & $\%$ \\
\hline $1-5$ & 18 & 18 & 38 & 42 & 52 & 63 \\
\hline $1-10$ & - & - & 11 & 12 & 3 & 4 \\
\hline Don't know & 80 & 82 & 41 & 46 & 27 & 33 \\
\hline TOTAL & 98 & 100 & 90 & 100 & 82 & 100 \\
\hline
\end{tabular}

Source: Field Work

Table 13: Solid waste management practice

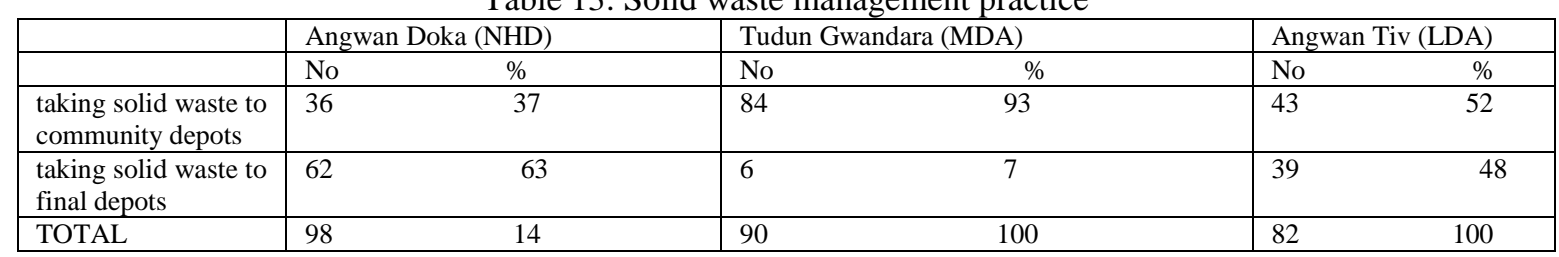

\section{Source: Field Work}

63 per cent of household heads interviewed in the high density area disposed their waste at the final depots. The reason here may be due to lack of regular clearing of waste in the area by tippers which encourage them to dispose in any depots created by the community as final depots. In the medium and low density areas, the situation is different because majority of household heads take their wastes to community collection centre. The reason may be due to access roads for easy movement of waste vehicles into and out of the areas. For the low density area, because of the available open spaces and fields resident may used such places as final depots.

Table 14: End uses/ End Products of solid waste

\begin{tabular}{|c|c|c|c|c|c|c|}
\hline & \multicolumn{2}{|c|}{ Angwan Doka (NHD) } & \multicolumn{2}{|c|}{ Tudun Gwandara (MDA) } & \multicolumn{2}{|c|}{ Angwan Tiv (LDA) } \\
\hline & & $\%$ & No & $\%$ & No & $\%$ \\
\hline Agricultural inputs & 7 & 7 & 26 & 29 & $\begin{array}{l}31 \\
38\end{array}$ & \\
\hline $\begin{array}{ll}\text { Industrial } & \text { raw } \\
\text { materials } & \end{array}$ & 6 & 6 & 38 & 42 & 40 & 49 \\
\hline Don't know & 85 & 87 & 26 & 29 & 11 & 13 \\
\hline 'TOTAL & 98 & 100 & 90 & 100 & $\begin{array}{l}82 \\
100\end{array}$ & \\
\hline
\end{tabular}

Source: Field Work 
The relationships between end uses/ end products are seen in spatial variation in the waste generated by households in the three density areas in Lafia. Table 14 shows that 87 per cent of household heads are not aware of the end products/uses in the high density area. The reason may be due to low level of educational attainment. In the medium and low density areas the situation is different; the reason may be due to high level of educational attainment and environmental awareness in the areas.

\section{Results And Discussion}

The findings of this study include the following, socio-economic characteristics of household heads in the three areas differs remarkably in term of household size, level of educational attainment, occupation and their level of income. The high density area has the highest average family size of 49 per cent which fall between 21-30 persons per household compared to the medium and low density areas which has 1-10 persons per household which is within the average national family size in most places. These difference calls for the differential in their perception of refuse disposal problem in the neighborhoods studied.

It was also deduced that all the major types of municipal solid waste are generated in all the areas, and majority of household heads in the three areas use either plastic or metal buckets to collect and disposed their waste. 71 per cent of household heads provides waste collection containers in their compounds, 69 per cent of households in the areas clear their refuse daily. With this result, it is expected that the environmental condition in terms of solid waste disposals should either be good or fair, but the town is still bedeviled by heaps of waste left at the depots created for waste disposal for a long time before been cleared.

The result also showed that 61 per cent of households dumped their solid waste at public waste depots which is the most acceptable means of waste disposal at the community levels. With only three functional vehicles at the disposal of Nasarawa State Urban Development Board which is totally inadequate for a town like Lafia. The results also showed that majority of household heads in the high density area are not aware of end uses and products of solid waste. It was also discovered that there is significant variation in the socio-economic characteristics of household heads in all the three study areas, and solid waste management problem is more severe in the high density area than in the low and medium density areas.

\section{Conclusion}

Towns and cities in Nigeria are expanding at very alarming rates in terms of population and waste generation which has now led to intractable environmental problems and quality. Lafia been the capital of Nasarawa State has since 1996 witnessed tremendous influx of people into the area which shares the same solid waste problem with other cities and towns in Nigeria. Thus, the following are conclusions of the study; i) the socio-economic characteristics household heads varies in the three areas ii) that solid waste management is more severe in the high density than in the medium and low density areas; and iii) all the major municipal solid waste are generated in the study areas.

\section{References}

[1]. American public work Association,(1975); Solid Waste Collection practices, Chicago administration services

[2]. Ogah, A.T. (2002). Community Participation in Solid Waste Management in Lafia, An M.sc thesis submitted to department of geography and Planning, University of Jos.

[3]. Gourlay, K.A. (1992), World of Waste Dilemmas, Industrial Development, Zed books, London.

[4]. Hickman, H. L., (1986). Collection of Residential Solid Waste in Robinson W D (ed). The Solid Waste Handbook: A Practical Guide. NY: John Wiley \& Son.

[5]. OECD (1976). "Recommendation of the Council on a Comprehensive Waste Management Policy" C. (76) 155 (Final) Paris

[6]. OCED (2000). Waste Management through prevention. Papers Presentations and Summary of the OECD Workshop On extended Producer Responsibility and Waste Minimisation Policy in support of Environmental Sustainability. 4-7 May 1999. Paris.

[7]. Oyediran, A.B.O., (1994), A Key note Address at the 6th Annual Workshop of Nigerian Environmental study/Action Team on 24th October, 1994, At the University of Ibadan conference centre, Ibadan.

[8]. USEPA (2000), Internet pages on climate change and waste Programme, http://www.epa.gov/globalwarming/actions/waste/

[9]. Sandbank, F.,(1980). Environmental Ideology and policy Basil Blackwell publishers,England, PP.183-195

[10]. Schaper, L. T., (1986). "Transfer of Municipal Solid Waste" The Solid Waste Handbook NY: John Wiley \& Son. 